\title{
Front Matter: Volume 7604
}

, "Front Matter: Volume 7604," Proc. SPIE 7604, Integrated Optics: Devices, Materials, and Technologies XIV, 760401 (9 March 2010); doi:

10.1117/12.859326

SPIE. Event: SPIE OPTO, 2010, San Francisco, California, United States 


\section{PROCEEDINGS OF SPIE}

\section{Integrated Optics: Devices, Materials, and Technologies XIV}

Jean-Emmanuel Broquin

Christoph M. Greiner

Editors

25-27 January 2010

San Francisco, California, United States

Sponsored and Published by

SPIE

Volume 7604

Proceedings of SPIE, 0277-786X, v. 7604 
The papers included in this volume were part of the technical conference cited on the cover and title page. Papers were selected and subject to review by the editors and conference program committee. Some conference presentations may not be available for publication. The papers published in these proceedings reflect the work and thoughts of the authors and are published herein as submitted. The publisher is not responsible for the validity of the information or for any outcomes resulting from reliance thereon.

Please use the following format to cite material from this book:

Author(s), "Title of Paper," in Integrated Optics: Devices, Materials, and Technologies XIV, edited by Jean-Emmanuel Broquin, Christoph M. Greiner, Proceedings of SPIE Vol. 7604 (SPIE, Bellingham, WA, 2010) Article CID Number.

ISSN 0277-786X

ISBN 9780819480002

Published by

SPIE

P.O. Box 10, Bellingham, Washington $98227-0010$ USA

Telephone +1 3606763290 (Pacific Time) · Fax +1 3606471445

SPIE.org

Copyright (C) 2010, Society of Photo-Optical Instrumentation Engineers

Copying of material in this book for internal or personal use, or for the internal or personal use of specific clients, beyond the fair use provisions granted by the U.S. Copyright Law is authorized by SPIE subject to payment of copying fees. The Transactional Reporting Service base fee for this volume is $\$ 18.00$ per article (or portion thereof), which should be paid directly to the Copyright Clearance Center (CCC), 222 Rosewood Drive, Danvers, MA 01923. Payment may also be made electronically through CCC Online at copyright.com. Other copying for republication, resale, advertising or promotion, or any form of systematic or multiple reproduction of any material in this book is prohibited except with permission in writing from the publisher. The CCC fee code is 0277-786X/10/\$18.00.

Printed in the United States of America.

Publication of record for individual papers is online in the SPIE Digital Library.

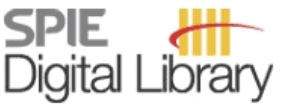

SPIEDigitalLibrary.org

Paper Numbering: Proceedings of SPIE follow an e-First publication model, with papers published first online and then in print and on CD-ROM. Papers are published as they are submitted and meet publication criteria. A unique, consistent, permanent citation identifier (CID) number is assigned to each article at the time of the first publication. Utilization of CIDs allows articles to be fully citable as soon they are published online, and connects the same identifier to all online, print, and electronic versions of the publication. SPIE uses a six-digit CID article numbering system in which:

- The first four digits correspond to the SPIE volume number.

- The last two digits indicate publication order within the volume using a Base 36 numbering system employing both numerals and letters. These two-number sets start with 00, 01, 02, 03, 04 , 05, 06, 07, 08, 09, OA, OB ... 0Z, followed by 10-1Z, 20-2Z, etc.

The CID number appears on each page of the manuscript. The complete citation is used on the first page, and an abbreviated version on subsequent pages. Numbers in the index correspond to the last two digits of the six-digit CID number. 


\section{Contents}

ix Conference Committee

xi Introduction

SESSION 1 WAVEGUIDE ENGINEERING I

760402 Integrated photonic devices for advanced modulation formats (Invited Paper) [7604-01]

Y. Hibino, NTT Corp. (Japan)

760403 High performance optical waveguides based on boron and phosphorous doped silicon oxynitride [7604-02]

F. Sun, A. Driessen, K. Wörhoff, Univ. of Twente (Netherlands)

760404 Accessing diamond waveguides and future applications [7604-03]

M. P. Hiscocks, The Univ. of New South Wales (Australia); C.-H. Su, K. Ganesan, B. C. Gibson, A. D. Greentree, L. C. L. Hollenberg, The Univ. of Melbourne (Australia); F. Ladouceur, The Univ. of New South Wales (Australia); S. Prawer, The Univ. of Melbourne (Australia)

760405 Waveguides based on TeGe thick films for spatial interferometry [7604-04]

E. Barthélémy, S. Albert, C. Vigreux, A. Pradel, Institut Charles Gerhardt, Univ. Montpellier 2 (France); X.-H. Zhang, S. Zhang, Sciences Chimiques de Rennes, Univ. de Rennes 1 (France); G. Parent, Lab. d'Energétique et de Mécanique Théorique et Appliquée (France); T. Billeton, Lab. de Physique des Lasers, Univ. Paris Nord (France); J.-E. Broquin, Institut de Microélectronique, Electromagnétique et Photonique (France); S. Ménard, M. Barillot, Thales Alenia Space (France); V. Kirschner, European Space Agency (Netherlands)

760406 Fabrication and characterization of $\mathrm{As}_{2} \mathrm{~S}_{3} / \mathrm{Y}_{3} \mathrm{Fe}_{5} \mathrm{O}_{12}$ and $\mathrm{Y}_{3} \mathrm{Fe}_{5} \mathrm{O}_{12} / \mathrm{SOI}$ strip-loaded waveguides for integrated optical isolator applications [7604-05]

L. Bi, J. Hu, L. Kimerling, C. A. Ross, Massachusetts Institute of Technology (United States)

760407 Microfluidics and thin-film processes: a recipe for organic integrated photonics based on 3D microresonators [7604-06]

N. Huby, D. Pluchon, M. Belloul, A. Moreac, Institute of Physics of Rennes, CNRS, Univ. de Rennes 1 (France); N. Coulon, Institute of Electronics and Telecommunications, CNRS, Univ. de Rennes 1 (France); E. Gaviot, Lab. of Acoustics, CNRS, Univ. du Maine (France);

P. Panizza, B. Bêche, Institute of Physics of Rennes, CNRS, Univ. de Rennes 1 (France)

\section{SESSION 2 AMPLIFIERS AND LASERS}

760408 Rare-earth-ion-doped $\mathrm{Al}_{2} \mathrm{O}_{3}$ for integrated optical amplification (Invited Paper) [7604-07] K. Wörhoff, J. D. B. Bradley, L. Agazzi, M. Pollnau, Univ. of Twente (Netherlands)

7604 OA Optofluidic FRET dye laser controlled by DNA scaffolds [7604-09]

Y. Sun, C.-S. WU, X. Fan, Univ. of Missouri, Columbia (United States) 
7604 OC Low threshold $\mathrm{Er}^{3+} / \mathrm{Yb}^{3+}$ co-doped microcavity laser [7604-11]

H.-S. Hsu, The Univ. of Southern California (United States); C. Cai, California Institute of Technology (United States); A. M. Armani, The Univ. of Southern California (United States)

\section{SESSION $3 \quad$ MODELLING}

7604 OD Large scale simulations in the realm of nanooptics (Invited Paper) [7604-12]

C. Rockstuhl, C. Etrich, C. Helgert, C. Menzel, T. Paul, S. Fahr, T. Pertsch, Friedrich-Schiller-Univ. Jena (Germany); J. Dorfmüller, R. Esteban, W. Khunsin, R. Vogelgesang, K. Kern, Max-Planck-Institut für Festkörperforschung (Germany); A. Dmitriev, Chalmers Univ. of Technology (Sweden); K. Bittkau, T. Beckers, R. Carius, Forschungszentrum Jülich GmbH (Germany); F. Lederer, Friedrich-Schiller-Univ. Jena (Germany)

7604 OF Finite element method for accurate 3D simulation of plasmonic waveguides [7604-14] S. Burger, L. Zschiedrich, J. Pomplun, F. Schmidt, Zuse Institute Berlin (Germany) and JCMwave GmbH (Germany)

7604 OG Partial image revivals in a multi-channel directional-coupler [7604-15]

R. J. McCosker, G. E. Town, Macquarie Univ. (Australia)

SESSION $4 \quad$ PHOTONIC INTEGRATION

$7604 \mathrm{OI} \quad$ Generic packaging concepts in the frame of network of excellence ePIXnet [7604-17] T. Tekin, L. Zimmermann, Technische Univ. Berlin (Germany); H. Schröder, Fraunhofer IZM (Germany); P. Dumon, W. Bogaerts, Ghent Univ. (Belgium); J. V. Galan, P. Sanchis, Univ. Politécnica de Valencia (Spain); W. Whelan-Curtin, D. Beggs, Univ. of St. Andrews (United Kingdom)

7604 0J Quantum well intermixing in AllnGaAs MQW structures through impurity-free vacancy method [7604-18]

K.-H. Lee, J. O'Callaghan, B. Roycroft, Tyndall National Institute (Ireland); C. L. L. M. Daunt, Tyndall National Institute (Ireland) and Univ. College Cork (Ireland); H. Yang, J. H. Song, Tyndall National Institute (Ireland); F. H. Peters, Tyndall National Institute (Ireland) and Univ. College Cork (Ireland); B. Corbett, Tyndall National Institute (Ireland)

7604 OK Monolithic integration of optical mode-size converter and high-speed electroabsorption modulators using laterally undercut waveguide [7604-19]

T.-H. Wu, F.-Z. Lin, H.-J. Yan, J.-P. Wu, Y.-J. Chiu, National Sun Yat-Sen Univ. (Taiwan)

\section{SESSION 5 SUBWAVELENGTH/DIFFRACTIVE PHOTONICS}

7604 OM Leaky-mode resonance photonics: technology for biosensors, optical components, MEMS, and plasmonics (Invited Paper) [7604-21]

R. Magnusson, The Univ. of Texas at Arlington (United States) and Resonant Sensors Inc. (United States); D. Wawro, S. Zimmerman, Y. Ding, Resonant Sensors Inc. (United States); M. Shokooh-Saremi, The Univ. of Texas at Arlington (United States); K. J. Lee, Univ. of Connecticut (United States); D. Ussery, The Univ. of Texas at Arlington (United States); S. Kim, Ajou Univ. (Korea, Republic of); S. H. Song, Hanyang Univ. (Korea, Republic of) 
7604 ON High speed optical filtering using active resonant subwavelength gratings [7604-22] A. V. Gin, S. A. Kemme, R. R. Boye, D. W. Peters, J. F. Ihlefeld, R. D. Briggs, J. R. Wendt, A. R. Ellis, L. H. Marshall, Sandia National Labs. (United States); T. R. Carter, J. D. Hunker, Sandia Staffing Alliance (United States); S. Samora, LMATA Government Services LLC (United States)

760400 Deep-subwavelength focusing and steering of light in an aperiodic metallic waveguide array [7604-23]

L. Verslegers, P. B. Catrysse, Z. Yu, S. Fan, Stanford Univ. (United States)

7604 OP Application of resonant subwavelength gratings to a rotary position encoder [7604-24] R. R. Boye, D. W. Peters, J. R. Wendt, R. J. Shul, Sandia National Labs. (United States); S. Samora, S. G. Rich, LMATA Government Services, LLC (United States); T. Carter, Sandia Staffing Alliance, LLC (United States); A. L. Lentine, R. A. Kellogg, S. A. Kemme, Sandia National Labs. (United States)

\section{SESSION 6 NON-LINEAR DEVICES AND MODULATORS}

7604 OR Towards nonlinear photonic wires in lithium niobate (Invited Paper) [7604-26]

H. Hu, L. Gui, R. Ricken, W. Sohler, Univ. Paderborn (Germany)

7604 OU High-density integrated optics in ion-sliced lithium niobate thin films [7604-29]

G. Poberaj, M. Koechlin, F. Sulser, P. Günter, ETH Zürich (Switzerland)

\section{SESSION 7 WAVEGUIDE ENGINEERING II}

7604 OV Review: Tg - reversible glass door to fabrication of photonic devices and integrated circuits [7604-30]

A. B. Seddon, D. Furniss, Z. G. Lian, W. J. Pan, T. M. Benson, The Univ. of Nottingham (United Kingdom)

7604 OW Fabrication and optimization of Tantalum pentoxide waveguides for optical micro-propulsion [7604-31]

B. S. Ahluwalia, O. G. Hellesø, Univ. of Tromsø (Norway); A. Z. Subramanian, N. M. B. Perney, N. P. Sessions, J. S. Wilkinson, Univ. of Southampton (United Kingdom)

7604 0X Fabrication of buried-type waveguide with optical gates by nano ion-exchange method [7604-32]

T. Yano, E. Shokatsu, Tokyo Institute of Technology (Japan); H. Segawa, National Institute for Materials Science (Japan); S. Shibata, Tokyo Institute of Technology (Japan)

7604 OY Refractive index engineering by fast ion implantations: a generic method for constructing multi-components electro-optical circuits [7604-33]

A. J. Agranat, A. Gumennik, H. llan, The Hebrew Univ. of Jerusalem (Israel)

$76040 Z$ Highly photorefractive $\mathrm{Eu}^{3+}$ activated sol-gel $\mathrm{SiO}_{2}-\mathrm{SnO}_{2}$ thin film waveguides [7604-34] S. Berneschi, IFAC-CNR (Italy); S. N. B. Bhaktha, LPMC, CNRS, Univ. de Nice-Sophia Antipolis (France); A. Chiappini, A. Chiasera, M. Ferrari, IFN-CNR (Italy); C. Kinowski, S. Turrell, LASIR, CNRS, Univ. des Sciences et Technologies de Lille (France); C. Trono, M. Brenci, I. Cacciari, G. Nunzi Conti, S. Pelli, G. C. Righini, IFAC-CNR (Italy) 
760410 Enhanced fluorescence sensing with nano-apertures (Invited Paper) [7604-35] M. Diwekar, S. Attavar, S. Blair, The Univ. of Utah (United States); M. Davis, E. Gardner, MOXTEK, Inc. (United States)

760411 Realization of a NIR compact static Fourier transform spectrometer in glass integrated optics [7604-36]

B. Martin, A. Morand, IMEP-LAHC (France); L. Jocou, LAOG (France); P. Benech, G. Grosa, IMEP-LAHC (France); E. Le Coarer, P. Kern, LAOG (France)

760412 Design of metamaterial based sensors for pressure measurement [7604-37]

R. Aylo, P. P. Banerjee, Univ. of Dayton (United States); A. K. Ghosh, P. Verma, Univ. of Oklahoma (United States)

760413 Fiber-based optical Fabry-Pérot gas sensor for fast and on-column detection [7604-38] J. Liu, Y. Sun, Univ. of Missouri, Columbia (United States); G. Frye-Mason, Consultant (United States); A. K. Thompson, S. Ja, ICx Nomadics, Inc. (United States); X. Fan, Univ. of Missouri, Columbia (United States)

760414 Stationary Wave Integrated Fourier Transform Spectrometer (SWIFTS) [7604-39]

J. Ferrand, LAOG, UJF-CNRS (France); G. Custillon, IMEP-LAHC, INPG-UJF-CNRS (France); G. Leblond, LNIO, UTT (France); F. Thomas, T. Moulin, E. le Coarer, LAOG, UJF-CNRS (France); A. Morand, IMEP-LAHC, INPG-UJF-CNRS (France); S. Blaize, LNIO, UTT (France); T. Gonthiez, Floralis (France); P. Benech, IMEP-LAHC, INPG-UJF-CNRS (France)

$760415 \quad$ Integrated optical chip in fiber optic gyros [7604-40]

V. Chunduru, R. VaraLakshmi, Dhanunjay, Karthik, Osmania Univ. (India)

\section{SESSION 9 PLASMONICS I}

760417 Experimental characterization of dispersion in plasmonic nanostripes for integrated DNA sensing [7604-42]

P. Steinvurzel, Harvard Univ. (United States); T. Yang, Harvard Univ. (United States) and Univ. of Michigan - Shanghai Jiao Tong Univ. Joint Institute (China); K. B. Crozier, Harvard Univ. (United States)

760418 Guided subwavelength optical mode with slow group velocity supported by a periodic plasmonic waveguide [7604-47]

L. Yang, C. Min, G. Veronis, Lovisiana State Univ. (United States)

760419 Nanoplasmonic couplers and modulators based on metal-insulator-metal structures [7604-44]

Z. Lu, R. Yang, R. A. Wahsheh, M. A. G. Abushagur, Rochester Institute of Technology (United States)

\section{SESSION 10 PLASMONICS II}

7604 1B Manipulation of near field polarization by far field excitation [7604-46]

S.-Y. Chen, A. A. Lazarides, Duke Univ. (United States) 
7604 1C Efficient sensitivity analysis of surface plasmon waveguide structures [7604-43]

M. A. Swillam, M. H. Bakr, X. Li, McMaster Univ. (Canada)

\section{POSTER SESSION}

7604 1D Detailed observation of optical intensity and frequency signal transmission in random metal-dielectric film [7604-48]

M. Fukuda, K. Yamaguchi, Toyohashi Univ. of Technology (Japan)

7604 IF Label-free biosensors with enhanced sensitivity based on polymer waveguide Bragg reflectors [7604-50]

J.-W. Kim, K.-J. Kim, M.-C. Oh, Pusan National Univ. (Korea, Republic of)

Author Index 
Downloaded From: https://www.spiedigitallibrary.org/conference-proceedings-of-spie on 26 Apr 2023

Terms of Use: https://www.spiedigitallibrary.org/terms-of-use 


\title{
Conference Committee
}

\author{
Symposium Chair
}

E. Fred Schubert, Rensselaer Polytechnic Institute (United States)

Symposium Cochairs

Liang-Chy Chien, Kent State University (United States)

James G. Grote, Air Force Research Laboratory (United States)

Program Track Chair

Yakov Sidorin, Quarles Brady LLP (United States)

Conference Chairs

Jean-Emmanuel Broquin, Institut de Microélectronique

Électromagnétisme Photonique/Laboratoroire d'Hyperfréquence et Caractérisation (France)

Christoph M. Greiner, LightSmyth Technologies, Inc. (United States)

Conference Cochairs

Gualtiero Nunzi Conti, Istituto di Fisica Applicata Nello Carrara (Italy)

Christoph A. Wächter, Fraunhofer-Institut für Angewandte Optik und Feinmechanik (Germany)

Program Committee

Pierre Berini, University of Ottawa (Canada)

Pavel Cheben, National Research Council Canada (Canada)

Xudong Fan, University of Missouri, Columbia (United States)

Helmut Heidrich, Fraunhofer-Institut für Nachrichtentechnik

Heinrich-Hertz-Institut (Germany)

Andrea Melloni, Politecnico di Milano (Italy)

Robert L. Nelson, Air Force Research Laboratory (United States)

Jens H. Schmid, Canadian Photonics Fabrication Centre (Canada)

Frank Schmidt, JCMwave GmbH (Germany) and Zuse Institute Berlin (Germany)

Yakov Sidorin, Quarles Brady LLP (United States)

Stefano Taccheo, Swansea University (United Kingdom) 


\section{Session Chairs}

1 Waveguide Engineering I

Gualtiero Nunzi Conti, Istituto di Fisica Applicata Nello Carrara (Italy)

2 Amplifiers and Lasers

Jean-Emmanuel Broquin, Institut de Microélectronique

Électromagnétisme Photonique/Laboratoroire d'Hyperfréquence et Caractérisation (France)

3 Modelling

Christoph A. Wächter, Fraunhofer-Institut für Angewandte Optik und Feinmechanik (Germany)

4 Photonic Integration

Stefano Taccheo, Swansea University (United Kingdom)

5 Subwavelength/Diffractive Photonics

Christoph M. Greiner, LightSmyth Technologies, Inc. (United States)

$6 \quad$ Non-Linear Devices and Modulators

Jens H. Schmid, Canadian Photonics Fabrication Centre (Canada)

$7 \quad$ Waveguide Engineering II

Yakov Sidorin, Quarles Brady LLP (United States)

$8 \quad$ Sensing

Xudong Fan, University of Missouri, Columbia (United States)

9 Plasmonics 1

Pierre Berini, University of Ottawa (Canada)

10 Plasmonics II

Robert L. Nelson, Air Force Research Laboratory (United States) 


\section{Introduction}

Since the concept of Integrated Optics was introduced by Miller in 1969, this field of research has kept evolving year after year, renewing itself constantly and, sometimes, surprisingly. Indeed, though the telecom bubble exploded, Integrated Optics kept on moving, finding applications in sensors and bio-chips but also in fields that may appear unlikely upon first glance, such as Astronomy.

This wealth of Integrated Optics applications is accompanied by a great breadth of technological and design approaches. From the well-known "Silica-on silicon" based waveguides to new plasmonic devices, from microresonators to diffractive devices, the conference Integrated Optics: Devices, Materials, and Technologies has been trying to reflect the vitality and the diversity of this field. In these proceedings, the reader will therefore see new advanced work on diamond waveguides and mid-infrared waveguides, as well as the "re-invention" of Lithium Niobate devices thanks to the use of ion-slicing.

The reader will find articles written by students, who quite often gave their first international talk at this conference, together with papers from renowned scientists of the field. It is indeed because today's students are tomorrow's scientific leaders that our conference has a long-standing tradition of promoting their participation and will keep on doing so, enabled by the generous SPIE student grant policy.

If Integrated Optics: Devices, Materials, and Technologies is now one of the oldest conferences of the SPIE Optoelectronics symposium, it is, on one hand, due to the high quality of the scientific work that has been presented throughout the years, and, on the other hand, it is also due to the dedication of its program committee members who willingly spend part of their summertime building the conference and finding the exciting invited talks that we see every year. To them, to the speakers and authors, and to the SPIE staff that makes the logistics run so smoothly, we would like to express our gratitude. We are looking forward to seeing you next year!

\section{Jean-Emmanuel Broquin Christoph M. Greiner}


Downloaded From: https://www.spiedigitallibrary.org/conference-proceedings-of-spie on 26 Apr 2023

Terms of Use: https://www.spiedigitallibrary.org/terms-of-use 